\title{
Research on the Contract Law of Commercial Prepaid Card
}

\author{
Wei Siyu \\ Shaanxi Vocational and Technical College, Shanxi,Xi'an710100
}

\begin{abstract}
With the development of the society, the new method of payment is emerging. Because Commercial prepaid card has adapted to the development of information technology and the objective need of market innovation about micropayments service, it is becoming a new means of payment. In real life, there are more and more disputes between merchants and consumers which are caused by the prepaid card contract. The clear requirements of both parties' rights and obligations about the prepaid card contract have become more and more urgent. This paper mainly adopts the methods of empirical investigation and comparative analysis. By comparing the internatinal regulation of commercial prepaid card, we investigate the contract practice of commercial prepaid card in real life and explore the issues about contract law of the commercial prepaid card.
\end{abstract}

\section{Key Words: Contract Law; Prepaid Card}

\section{INTRODUCTION}

At present the theoretical research and legislative proposals about commercial prepaid card focuses on guarding against financial risks, being strict with financial and tax management, governing the bribe-taking with coollecting the card and other aspects. The research on the contract law issue about commercial prepaid card scatters and doesn't form a system. It mainly concentrates in the limited clauses about the prepaid card, and whether the prepaid card can refund and other loose issues. The author thinks that as a means of commercial activities among the equal subjects, the contract law issue of commercial prepaid card is worth studying.
Commercial prepaid card represents that we establish the relationship of civil rights and obligations between the cardsender and the cardholder and set up a kind of contractual relationship. The researches on the validity of the contract itself, the rights and obligations of the two parties and contract relief problem are of great significance to both parties' responsibility partition and protection, especially the protection of the card holders' interests. The author hopes to use this paper about the research on contract law of commercial prepaid card to clarify the rights and obligations of all contractual parties and puts forward his own suggestions about the protection of cardholder interests and the regulation of commercial prepaid card.

2. The Influence of Commercial Prepaid Card ANd Legal Problems WHICH We OfTEN ENCOUNTER

Commercial prepaid card with stumbling development today has a variety of impacts on China's social economy. Its twists and turns of development process indicates that it is the choice which is made by the society and the government after they make the balance between its negative effects and positive effects. Commercial prepaid card has double influence on the society. On one hand, it is convenient to the payment of the consumers. It provides certain benefits for the consumers( Regardless of the reality about this kind of tangible benefits). And it provides effective ways for the raising and pooling money of the merchants, expanding the scale further, and so on. At the same time, it also 
promotes the domestic demand to accelerate the product turnover and reduce the transaction cost of the whole society. on the other hand, it also brings negative influence on our social life. At present the negative impacts about commercial prepaid card are concentrated in the following four aspects.

First, it has had a powerful impact upon the position of RMB. And it not conducive to the realization of the functions of the peopl's bank. Second, it has brought difficulties to the tax administration. The prepaid card often gets into the position which is suspected of evading the national taxes. Third, The prepaid card has brought the corruption problems. On the one hand, the disordered issuance and application of commercial prepaid card has stimulated the consumption with public money to make the deformity of consumption. And it also contributes to unhealthy practices such as corruption, waste, and so on. On the other hand, commercial prepaid cards are generally paid by small amount. So it is easy to purchase card, and it can be changed into the cash quickly. The transactions are concealed without leaving any traces, and people feel at ease when they receive bribery. Fourth, the problems about violating consumer's benefits which is brought by commercial prepaid cards are the legal problems commonly encountered by us which the author wants to say in this section. These legal problems may be varied.

\section{The Legal Nature of Contract about Commercial Prepaid Card}

The first problem about the analysis of contract law is to clarify the legal nature of consuming behavior about the prepaid card. Many scholars believe that the prepaid card itself is not a contract, and the prepaid card is a kind of right certificate. However, if we use the right certificate to talk about the prepaid card, is seems to be too broad. So-called right certificate refers to the the evidence which can prove the existence of legal rights. The patent certificate is right certificate. House proprietary certificate is right certificate. The contract is also a kind of right certificate. However, they all represent different legal relationship. what kind of legal nature does the commercial prepaid card belong to? Obviously if we just say that it is right certificate, it is just not enough.

To clarify the legal nature of commercial prepaid card, first of all we should understand the legal relationship which exists among all the parties involved in the consumption behavior. As far as the prepaid cards which are issued by their own people are concerned, they involve two parties, that is to say, one party is the provider of the commodity or service ( the merchants), and the other party is the card purchaser (Assuming that the card purchaser is consistent with the cardholder in the following analysis), and both parties are the contracting parties of the contract about the prepaid cards. While as far as the distribution type prepaid card of the third party is concerned, it involves three parties, namely the prepaid card issuers, the merchants, the card purchaser. The relationship between the issuers and the merchants is the agency relationship, and the agent's power is to substitite for the merchants to issue prepaid card ( Or the issuers will also substitite for the merchants to sell.) The merchants and the card purchasers are the contract parties in the contract of the prepaid card. Because the third party is not involved in the contract of the prepaid card, in order to be convenient to analyze, the author only analyzes the behaviors of the merchants and the card purchasers. 


\begin{tabular}{|l|l|l|}
$\begin{array}{l}\text { The merchants set the } \\
\text { rules for consumption, } \\
\text { the rules about the use } \\
\text { of funds and the prepaid } \\
\text { limit, etc, and inform } \\
\text { the consumer. }\end{array}$
\end{tabular}

Fig 1. The behaviors of the merchants and the card purchasers.

We can see from the flowchart that the merchants will set the rules for consumption in advance first. The merchants mainly explain the content of goods or services provided by them and specific consumption rule. Then the merchants will set the rules about the use of funds and the prepaid limit and make them be informed to the consumers. Consumers may choose particular prepaid cards and pay a certain amount of money with all kinds of reasons, such as convenient carrying of the prepaid cards, convenient payment, cheap price or fashion and so on. Then consumers can use prepaid card to consume in the designated places. It is important to note that because the goods and the consumption way provided by supermarkets, shopping malls and other retail stores basically have been stereotyped and have tended to be the same, and the consumers are not easy to misunderstand their understanding, this kind of merchants don't need to explain these contents any more when they issue the prepaid cards. While the prepaid card providers with service types, such as fitness, bath center and so on need to make detailed explanation. In addition, the issuers may also do not quite understand the content and the consumption rules provided by the merchants. The consumers may only understand the payment and the usage rules of the prepaid card best, and for the other things they may understand them when they need to understand them. In this case, the judgement of the consumers about all kinds of benefits brought by the prepaid card is just a judgment with common sense.

There are different theories for the nature of the contract about the commercial prepaid card. There are mainly three theories, namely the theory of offer - promise, the theory of appointment - contract and the theory of consumuption contract.

\section{The Contract EfFectiveness of Commercial PREPAID CARD}

Contract Effectiveness of Commercial Prepaid Card has long been questioned. The development of commercial prepaid card is a long process. The various policies on commercial prepaid card are as follows:

In 1991, the General Office of the State Council issued a notice that the use of scrip coupons be forbidden (state issued [1991] no. 28 document). This notice takes a negative attitude towards the use of money-substitute cards.

On January 19, 2001, the Institute of Correcting the Bad Vogue in State Council Office with the National Economics and Trade and The People's Bank of China, the above three ministries jointly issued a formal notice---Notice About Prohibiting the Use of Scrip Coupons, to reiterate the ban.

In 2005, The People's Bank of China issued The Methods of Organizing and Administrating Payment Liquidation (opinion soliciting draft). In August 2006, Department of 
Commerce, State Development and Reform Commission issued Administrating Methods with the Sales Promotion Behavior of Retailers, the China Banking Regulatory Commission issued Notice About Banning the Distribution of Co-Branded Card by Banks and Business Institutions. In March 2007, the Beijing Municipal Commerce Bureau, the Beijing Municipal Development and Reform Commission issued Detailed Rules of the Sales Promotion Behavior of Retailers, in 2008, Xiamen issued similar document. The Announcement No. 7 [2009] of People's Bank of China is unveiled in 2009, the next year The Administrating Payment Service Methods of the Non-Financial Institutes is unveiled, followed by the unveiled Notice About the Opinions of Prepaid Card Management in May 2011. Prepaid commercial card went through a long process, and the state and society have reached a consensus towards it- "Direction" rather than "Blockage".

Although according to the regulations of the 20th article in The Laws of People's Bank of China: "any unit or individual is prohibited to print or release promissory notes as substitutes for RMB to circulate on the market". The law is passed by the National People's Congress (NPC) and is implemented, thus it belongs to the special law, which is the upper law of the above legal documents. So in theory, the contract of commercial prepaid card should be ineffective for breaking the mandatory provisions of the law. However, in terms of the present situation of our country's legal facts, the above documents have more strong executive power in real life.

So from the above legal documents, it is easy to see that the contract of prepaid card has become a legal contract. As long as it conforms to the general legal requirements of the contract.
That is to say, the contract actor possesses civil conduct ability, his intention can be truly shown and he doesn't violate of laws or the administrative rules and regulations, then the contract is effective.

\section{Suggestions of China's Commercial Prepaid CARD Contract Regulation}

The rules of contract law for commercial prepaid card are primarily a advance boot and afterwards relief, and this is definitely not the main aspect of prepaid card regulation.

First of all, according to the nature of the contract, main rights and obligations between both parties of the commercial prepaid card should be made clear. For reserved prepaid card, the rights and obligations of the contract itself should be mainly made clear, including the types of cards (Prescription card, times count card, stored value card, and time count card), costs, modes of payment (cash, bank card, checks, etc.), limits of authority (such as whether the card is transferable, whether it needs to pay a transfer fee, whether registered or not, whether it can be used by any cardholder, whether it can participate in other preferential promotion, etc.), expiry date (including the disposal of the remaining amounts when the time limits expires), use range and so on. For consumer service prepaid card, in addition to the above mentioned information, the detailed service rules should also be known in handling the card, and the form of a gift card should adopt the prepaid card in association with merchant service articles, products, detailed service.

Secondly, set up the card and the balance refund mechanism. Stipulated that when the prepaid cards can no longer perform or continue to perform, the contract does not meet the interests of the parties, and do not comply with the justice principles, the contract should be 
terminated, and the balance be returned based on the general provisions of contract law. Based on reasonable calculation, the balance that has not been used should be returned. For example, as far as the gift card is concerned, the rest of the money should be returned. As far as the gym membership card is concerned, the proportioned funds that services without consuming occupy a certain proportion of the whole contract services should be returned.

Thirdly, strengthen the formalization of the prepaid card. For the contract that needs consultation at that time, the contract should be signed in accordance with the agreed result. For the part does not require consultation, such as general terms and conditions, the written form of provided general terms and conditions will be needed. When the prepaid card contract is made, all kinds of agreements of both parties mainly should be used the written form to be fixed as much as possible. For the provider of the commodity or the service showed on prepaid card, there must be data backup of the consumption of the articles, rules, detailed information of product for your query. At the same time there should also be data backup of basic information, such as the merchants' name, the organization code, the director and his contact methods. Finally, formal legal bills should be issued in consumption.

\section{CONCLUSIONS}

After ten years of development, commercial prepaid card has been improved continuously. As the industry regulatory department is gradually known to people, supervision laws and regulations gradually perfect themselves, self-discipline organizations appears, and other relevant policies is issued, the ecological system of commercial prepaid card industry has gradually shaped.

The legislative regulation of commercial prepaid card should be conducted from multiple angles. For a long time, our country gathered the problem of commercial prepaid card mostly in three aspects. Firstly, it is the impact of commercial prepaid card on finance, including the influence on the banking functions, on our country's settlement and a variety of business risks. Secondly, it is the tax issues brought about by commercial prepaid card. Thirdly, it is the function of commercial prepaid card which produces the problems of the corruption and the money laundering. But as a means of economic activity,commercial prepaid card itself at the same time is an innovative way for the civil actors of equal status which conducts marketing activities. As a kind of contract, commercial prepaid card is also worth of studying. It needs us to regulate. In real life, there are more and more disputes between merchants and consumers caused by prepaid card contract. Thus, it becomes more and more urgent for both parties to be clear about the rights and obligations of the prepaid card contract.

\section{Reference}

[1]Anonymous. Research and Markets: The New Financial Cards In The United Kingdom Report establishes the size and structure of the market for ATMs cards, smart cards, credit cards, debit cards, charge cards, pre-paid cards and store card[J]. M2 Presswire,2008,:.

[2]Anonymous. Research and Markets: Retailing in Japan - Affiliations With Pre-paid Cards A Key To Gaining Loyal Customers[J]. M2 Presswire, 2009,:

[3]Anonymous. Research and Markets; Pre-paid Cards - Greece: Pinpoint growth sectors and identify factors driving change[J]. Computer Weekly News,2011,:

[4]Gold, Jon. Google Wallet to lose pre-paid card option[J]. EN,2012. 